\title{
From Farm Tools to Electric Cars
}

A Study of the Development of a Chinese Industrial Cluster: The Case of Yongkang in Zhejiang (1980-2010)

\section{Shi Lu and Bernard Ganne}

Translator. Will Thornely

\section{(2) OpenEdition}

\section{Journals}

\section{Electronic version}

URL: http://journals.openedition.org/chinaperspectives/6916

DOI: 10.4000/chinaperspectives.6916

ISSN: 1996-4617

\section{Publisher}

Centre d'étude français sur la Chine contemporaine

\section{Printed version}

Date of publication: 1 March 2016

Number of pages: $37-48$

ISSN: 2070-3449

\section{Electronic reference}

Shi Lu and Bernard Ganne, "From Farm Tools to Electric Cars », China Perspectives [Online], 2016/1 |

2016, Online since 01 March 2017, connection on 28 October 2019. URL : http://

journals.openedition.org/chinaperspectives/6916; DOI : 10.4000/chinaperspectives.6916 


\title{
From Farm Tools to Electric Cars
}

\author{
A Study of the Development of a Chinese Industrial Cluster: The Case of Yongkang in \\ Zhejiang (1980-2010)
}

\author{
SHI LU AND BERNARD GANNE
}

\begin{abstract}
It is now recognised that China's industrial clusters have played a particularly significant part in the prodigious economic transformations the country has experienced since the launch of reforms at the end of the 1970s. By studying the case of Yongkang, a county-level city in Zhejiang Province specialising in the manufacture of metal products, this article aims to increase understanding of how this rural area with a tradition of small-scale metal production has become, over the course of a few decades, an industrial cluster built around specific operations, and which economic, social, and political approaches have made these transformations possible.
\end{abstract}

KEYWORDS: Zhejiang, Yongkang, company, industrial cluster, economy, governance, market.

\section{Introduction}

$t$ is now recognised that industrial clusters - or concentrations of production industries of the same sector in the same area - have played a particularly significant part in the prodigious economic transformations that China has been through over the past 30 years. This intense development of specialised industries in specific areas has taken place with force and at speed, employing approaches that have, in many respects, been surprising and diversified, and the importance of which has not always been clearly anticipated.

Although it is Professor Fei Xiaotong who, by forging the concept of "parceled economies" (kuaizhuang jingji 块状经济) in his work on the industrialisation of the countryside in Zhejiang Province at the start of the 1980s, can be credited as the first to identify the phenomenon of clusters, it was not until after 2000 that researchers truly started to grasp the concept and analyse it in all its diversity. Since the emergence of works from geographers, including Professor Wang Jici's compendium, (1) economists and sociologists from Sun Yat-Sen University, (2) and economists and managers from Zhejiang University, ${ }^{(3)}$ to cite but a few, there has been no let-up in the growth in the number of studies, symposiums, and research websites focusing on industrial clusters, and with the central government introducing a cluster policy extending to other territories, including the provinces in western China, research in this field has intensified still further. ${ }^{(4)}$

These early studies sought, above all, to explain the expansion of the phenomenon. Indeed, a quarter of the 404 administrative cities on the Pearl River Delta in Guangdong Province were clusters built around specialised activities, while Zhejiang Province was home to more than 300 specialised areas, some of which now occupy leading positions in international markets.

This research also showed the diversity of the industrial clusters:

- the diversity of structures, first and foremost, since clusters of traditional industrial firms (textiles, clothing, shoes, metal working, etc.) should be distinguished from high-tech clusters, which in turn differ from clusters arising from investment by foreign companies, or clusters of SMEs gathered around large companies; ${ }^{(5)}$
- there are also considerable disparities between the different provinces. For example, the dynamic of the clusters of Guangdong, which are driven in particular by the proximity of Hong Kong and more exogenous currents of investment and economic development, should not be confused with that of areas where a more strictly local and endogenous form of development holds sway, such as that observed in Jiangsu or Zhejiang Province, for example. ${ }^{(6)}$

The latter province, moreover, experienced development on a level previously relatively unseen, and which led to certain researchers drawing comparisons with the growth of Italian industrial districts in Europe in the 1960s, both in terms of form - given the concentration of SMEs in the same sectors of activity - and scale: despite being relatively deprived and lacking in major economic assets, Zhejiang rose in the GNP ranking of Chinese provinces from $12^{\text {th }}$ place in 1978 to $4^{\text {th }}$ in $2000,{ }^{(7)}$ owing to its system of industrial districts, which the Chinese government wishes to roll out to other more disadvantaged regions of the country. As a result of its mainly endogenous development, and its very high concentration of private companies $(82.8 \%$ of the provincial industrial infrastructure in

1. Wang Jici, Chuangxin de kongjian: qiye jiqun yu quyu fazhan (Innovation Space: Industrial Clusters and Regional Development), Beijing, Beijing daxue chubanshe, 2001.

2. Rigas Arvanitis, Pierre Miège, and Zhao Wei, "A Fresh Look at the Development of a Market Economy in China," China Perspectives, No. 48, 2003, pp. 51-62.

3. Zhang Shuguang and jin Xiangrong, Zhongguo zhidu bianqian de anli yanjiu (Case Studies of Institutional Change in China), Hangzhou, Zhejiang daxue chubanshe, 2006.

4. Since 2002, an international symposium has been held annually in different cities to discuss clusters and regional development (Chanye jiqun yu quyu fazhan guoji xueshu yantaohui). Since 2007, China has been publishing annual reports on the industrial clusters (Zhongguo chanye jiqun fazhan baogao). 2005 saw the creation of the National Institute for Research into Industrial Clusters (Zhongguo chanye jiqun yanjiuyuan), which has organised industrial cluster congresses (Zhongguo chanye jiqun dahui) every year since 2010.

5. Wang Jici, Chuangxin de kongjian: qiye jiqun yu quyu fazhan (Innovation Space: Industrial Clusters and Regional Development), op. cit.

6. Zhu Huacheng, Zhejiang chanyequn: chanye wangluo, chengzhang guiji yu fazhan dongli (Industrial Clusters of Zhejiang: Networks, Trajectories and Development), Hangzhou, Zhejiang daxue chubanshe, 2003; Sheng Shihao, Zhejiang xianxiang: chanye jiqun yu quyu jingji fazhan (The Zhejiang Phenomenon: Industrial Clusters and Regional Economic Development), Beijing, Qinghua daxue chubanshe, 2004.

7. Zhejiang sheng tongji xuehui (Zhejiang Statistics Institute), Zhejiang sheng disan chanye fazhan zhuangkuang yanjiu (Study on the Development of the Tertiary Sector in Zhejiang), Zhejiang jingji cankao, 6 January 2012, p. 1. 
2012, a very high proportion being SMEs), (8) Zhejiang Province appears to be one of China's most remarkable models for development and transition to a market economy, the steps and characteristics of which have been described exhaustively:

- firstly, the re-emergence in the villages and townships of the province, during the 1980s, of a whole series of activities, initially small-scale and later industrial, becoming increasingly specialised in nature;

- a high degree of specialisation of areas into clusters during the $1990 \mathrm{~s}$ and until the early 2000s, in terms of both production and marketing activities;

- the development and extension, during the first decade of the 2000s, of new models of clusters centred on new energies and new technologies.

This model of change could seem quite ordinary if it were not marked by major particularities ${ }^{(9)}$ such as those observed in the city of Wenzhou, which is often held up as a leading example owing to the standing and dynamism of its family-owned and private SMEs, or Yiwu, which has now become a city of international trade and a market for wholesale products on a scale seen nowhere else in the world. ${ }^{(10)}$

In addition to these essential economic approaches, it was also necessary to understand the form taken by the cluster phenomenon. How was it possible, in mainly agricultural areas of a rural/socialist character and with no strong industrial tradition, for highly structured centres to form in such a short time around specific operations or specialised branches of activity? How was it possible, in the regions of this province most lacking in industrial activity, for areas with low levels of industrial activity to grow within the space of 30 years into centres highly specialised in areas of production and not only selling in China but also exporting to international markets? What economic, but also political and social approaches, made these changes possible? What forms of governance enabled, supported, or helped shape the construction of these local organisation systems that we refer to as clusters and that constitute one of the characteristics of Zhejiang?

These questions cannot be answered merely by examining global or general considerations. For this reason, we have chosen to consider the subject in the context of a case study of Yongkang, a county-level city located in the centre of Zhejiang, which in 2010 had a population of 868,200 , of whom 300,000 were migrants.

Yongkang has experienced an impressive level of growth over a 30year period. For many years, metal working existed alongside agriculture as a traditional economic activity in this former rural county. ${ }^{(11)}$ The city later became specialised in small metal products before expanding into the production of larger-scale products such as metal doors (70\% of China's national production in 2012), ${ }^{(12)}$ bicycles, motorbikes, and motor vehicle parts. Since 2008, it has also been producing electric vehicles and solar panels. This text looks at the various steps that have marked the development of the city of Yongkang, from farm tools to electric cars, since the launch of the economic reforms. In doing so, we will try to examine the factors and agents that have influenced these transformations, and in particular the ways in which the various levels of government, whether central or provincial, and more locally at the county, township, and town level, have been involved in the governance of the clusters in each period.

At each stage, we will see how public intervention practices are in a state of constant transformation, and the modes of governance evolv- ing. Understanding these factors should then make it possible to better grasp the turning point that Yongkang is experiencing, along with all of Zhejiang Province, and at the same time expand the ways in which we understand the functioning and variety of the different industrial clusters in China. ${ }^{(13)}$

\section{The melting pot for early activities and the emergence of small-scale workshops in the 1980 s}

\section{A base of traditional craft industry and peddling}

Yongkang is known for its tradition of small-scale metal production, which some have claimed dates back to the fifth century BC. For many years, metal products were manufactured in Yongkang for everyday or farming purposes, for example scales, cooking pots, knives, sickles, and axes. ${ }^{(14)}$ Two types of craftsmen lived in this rural area: sedentary craftsmen, who switched between agricultural activities and small-scale metal activities, and peddling craftsmen. The latter, referred to as "door-to-door salesman" (xingdan 行担), traveled the neighbouring regions and spend at least half of the year away from their villages in order to manufacture or repair farm tools or articles for everyday use.

At the start of the 1950s, Yongkang had more than 40,000 registered peasants also working as pedlars, accounting for $15 \%$ of the total population of the county. ${ }^{(15)}$ After the "socialist transformation" political campaign (shehui zhuyi gaizao 社会主义改造), which involved transforming the small-scale private operations of peasants into collective operations, independent craftsmen were all integrated into collective factories or state factories. In 1955 , as part of the first five-year plan launched two years earlier, all economic activities of a private nature were dismantled. In response to the general industrialisation policy of the central government, the traditional craftsmen of Yongkang were grouped together into cooperatives in order to provide spare parts to the few state factories, including the tractor factory, which was the largest in Yongkang. However, most of these cooperatives did not survive following the policy of readjustment announced by the cen-

8. Zhejiang Provincial Bureau of Statistics, "Cong tongji jiben danwei de bianhua kan Zhejiang siying qiye de shengcun zhuangkuang" (The Private Companies of Zhejiang Viewed through Statistical Data), 24 December 2013, www.zj.stats.gov.cn/tjfx_1475/tjfx_sjfx/201312/t20131 224_138538.html (accessed on 5 February 2015).

9. Shi Lu and Bernard Ganne, "Understanding the Zhejiang Industrial Clusters: Questions and Reevaluations," in Bernard Ganne and Yveline Lecler, Asian Industrial Clusters, Global Competitiveness and New Policy Initiatives, Singapore, World Scientific, 2009, pp. 239-266.

10. Ding Ke, Market Platforms, Industrial Clusters and Small Business Dynamics: Specialized Markets in China, Cheltenham, Edward Elgar Publishing, 2012.

11. Craftsmen manufactured tools for farm work (sickles, hoes, etc.) and utensils for use in the home (scissors, knives, etc.).

12. Juji menye fazhan liliang: 2012 Zhongguo menye fazhan qushi baogao (Bringing Together the Forces of the Door Manufacturing Sector: 2012 Report on the Development of the Door Sector in China), Yongkang jinbao, www.cbda.cn/html/qita/20130507/23929.html (accessed on 2 February 2015).

13. This work on Yongkang was carried out between 2006 and 2011 in the context of research on the Chinese clusters developed jointly with the IAO (Lyon's Institute of East Asian Studies) and the Max Weber Centre (CMW). It is based, in part, on a series of in-depth interviews with companies and local collectivities in Yongkang and in Yiwu during missions carried out during this period.

14. Traditional craft industries have always existed as an economic activity alongside farming in Zhejiang Province, in particular owing to the demographic importance of agriculture and the shortage of natural resources.

15. Yongkang shi zhengxie wenshi weiyuanhui (Commission of Cultural and Historical Data of the Political Consultative Conference of Yongkang), in Mantang zhi lu (The Path to Mantang), coll. Yongkang shi zhengxie wenshi weiyuanhui, 1996, p. 5. 
tral authorities in 1960. ${ }^{(16)}$ It was not until 1969 that the collective production workshops (shedui qiye 社队企业) reemerged. In 1978, there were approximately 1,000 of them in Yongkang. ${ }^{(17)}$

Parallel to this, and from the middle of the 1970s, although still strongly opposed by those with political power who objected to their private nature, peddling activities resurfaced, driven by poverty. Pedlars travelled throughout China to sell their traditional craft products, returning to their villages with information on the needs of external markets, which encouraged peasant families to embark on small-scale manufacturing in an attempt to meet these needs. The setting up of the household-responsibility system in 1978 was a pivotal event in the economic expansion of these activities.

\section{The conflictual emergence, "under local cover," of individual family businesses}

At the beginning of the 1980s, soon after economic reforms had been launched in rural China, peasants in Yongkang took advantage of the changes to swiftly develop their additional economic activities. Indeed, in 1981, workers were authorised by the central government to declare "individual businessman" status (getihu 个体户), provided they employed fewer than seven people. (18) However, the creation of private companies (of more than eight people) was still not encouraged.

Economic life in rural areas was then supposed to be organised around a collective system called collective production workshops (shedui qiye), which were the property of the local governments. The latter, out of political precaution and most probably also as a result of economic considerations, intensified their watchful eye over private economic activities, occasionally repressing them, as in the case of the village of Mantang in Yongkang. From the start of the economic reform, the peasants of Mantang had secretly engaged in small scale and commercial activities to sell their metal products in the village, district, and indeed province, as well as in neighbouring regions. So as to "cut off the capitalist tails" (ge zibenzhuyi de weiba 割资本 主义的尾巴) - as stated by the slogan of the time - the village managers arrested villagers who were carrying out manufacturing operations (approximately 80 arrests were made) and threatened to exclude them from the village.

This event triggered the transformations that were to follow. With a revolt brewing, the local government was obliged to change its tone and adopt a compromise. It agreed to turn a blind eye to the setting up of small-scale operations, on condition that they prosper under its cover. In this context, the local government ultimately encouraged the peasants to create family workshops in Mantang. Therefore, in 1982, no fewer than 170 of the 183 households in the village were registered as small-scale workshops, ${ }^{(19)}$ which was a first step in the development of traditional activities in the form of individual family businesses, aptly summed up by the slogan: "A workshop for each family, and companies in every village" (jiajia ban gongchang, cuncun ban qiye 家家办工厂, 村村办企业). (20)

\section{Workshops specialised in small scale metal working}

The only major industrial activity in the area was a state factory manufacturing tractors. Small-scale activities developed mainly in areas of industry based on metal work (production of forks, cutlery, small tools, etc.) that was carried out, in particular, using metal scrap and junk from the main factory, as well as scrap found elsewhere.
The owner of a company producing vacuum flasks in Yongkang describes below how he started out, with a story fairly typical of the paths followed by other craftsmen:

In 1980, I left for Guizhou, Sichuan, Anhui, Shaanxi, etc. These are regions where heavy industry had a major presence. I worked alone to collect metal from factories, transporting the metal off-cuts by train or lorry. I sold them in the village, pocketing the difference. I did that until 1984, by which time I'd been able to earn some money. I thought it made more sense to invest in industry than to merely do business as a middleman. In 1985, I created a workshop, which was officially affiliated with a collective factory. I used the name of this factory to keep under the cover of the "red hat" (hong maozi 红帽子). (21)

One day, a friend received an urgent order. He needed to manufacture spare fan parts from aluminium, but was unable to do so because he had no aluminium. Yet I had aluminium in stock. This friend proposed that I take on the order. We used basic and traditional manufacturing methods. There was no need for any complicated technical skills. After this first order, I entered this activity. I found a factory I could collaborate with in Anhui. (22)

This period, which saw the emergence of early small-scale activities that were more or less tolerated or "covered" by the local authorities, saw the development of a certain concentration of family workshops in villages and townships characterised by a degree of specialisation in terms of the goods produced. In the words of a slogan that emerged at the time, this translated into "one product per town and one sector per township" (yizhen yipin, yixiang yiye 一镇一品, 一乡一业). This system developed to the point that by the middle of the 1980s, 80 villages specialised in this way (zhuanye cun 专业村) had developed in Yongkang, including Mantang 墁塘, where $90 \%$ of the family workshops specialised in the production of spare parts for scales.

16. In 1960, in an official document, the central government stipulated the closure of the rural factories in the people's communes in order to promote agricultural activities. See Xin Yi, "Nongye 60 tiao de xiuding yu renmin gongshe zhidu de bianqian" (Revision of the 60 Rules of Agricultural Activities and Development of the Regime of the People's Commune), Zhonggong dangshi yanjiu, No. 7, 2012, pp. 39-52.

17. Chen Qibiao, "Dui jinqi Yongkang xiangzhen qiye fazhan de huigu" (Retrospective on the Development of Rural Factories in Yongkang), in Mantang zhi lu (The Path to Mantang), op. cit., pp. 17-21.

18. In 1979, following a meeting of the directors of the Trade and Industry Bureau, the CCP and the State Council published a document allowing economic activities on an individual basis in repairs and services by holders of the permanent hukou. In October 1981, the CCP and the State Council published a document allowing the creation of individual companies (getihu) employing a maximum of seven people. If they employed more than eight people, they were considered to be private companies (siying qiye). See Gilles Guiheux, "The Incomplete Crystallisation of the Private Sector," China Perspectives, No. 42, 2002, pp. 24-35.

19. Interview with Mr. Luo of Yongkang municipality, September 2009.

20. Bernard Ganne and Shi Lu, "Local Economic Development and Transformations of the Political Discourse and Practices in China: Case Analyses from the Zhejiang Region from the Eighties," European Journal of East Asian Studies, No. 10, 2011, pp. 203-226.

21. Since private companies were forbidden, they affiliated themselves with the companies of local collectivities. This was referred to as "borrowing the red hat" (jie hong maozi). These fictitious collective enterprises, opposed by the central government, were repressed between 1982 and 1984. See Cao Zhenghan, "Cong jie hong maozi dao jianli dangwei" (From the Red Hat System to the Creation of the (CP Committee), in Zhang Shuguang and Jin Xiangrong, Zhongguo zhidu bianqian de anli yanjiu (Case Studies in China's Institutional Change), op. cit, pp. 81-140. See also François Pavé and Li Youmei "La Chine actuelle et le marché : émergence des PME familiales dans la dynamique de développement économique" (Present-day China and the Market:The Emergence of Family SMEs in the Dynamic of Economic Development," Sociologie du Travail (Sociology of Work), No. 1, 1995, pp. 29-42.

22. We followed this businessman between 2006 and 2011. This passage is taken from our first interview with him, which took place in 2006. 
The negotiated establishment of a first more or less improvised system of local economic organisation

In this phase of emergence, the family workshops soon came up against major difficulties owing to the fact that the environment in which they operated suffered from a total lack of official economic organisation. It is important to understand that at this time, no system existed locally allowing independent small-scale companies to process such basic management operations as billing for a product, opening a bank account, paying employees, etc.

Starting in 1982-83, the village of Mantang therefore began to make arrangements to deal with these problems by local consultation. It first created a kind of confederation between the craftsmen and village authorities, bringing together all of the family workshops in the village with an official appointed by the village and responsible for all the administrative and financial steps taken by the workshops. It even developed a system of payments in order to fund shared services while also ensuring the approval of local governments: a bona fide tax system was negotiated, under which $1 \%$ of the total of sales would be paid to the commune, $3 \%$ to the village, and $5 \%$ to the state.

A former official of the Yongkang city council, who at this time kept the $\log$ of these events, gave the following account:

In 1981, it became possible to set up as an independent businessmen (getihu), but such entrepreneurs ran into three types of problems: private businessmen were not able to invoice for their products, since they lacked authorisation documents from the village; they could not open a company bank account; and there were no regulations concerning the payment of employees. This meant they needed to join the collectivity. A confederation was created in order to circumvent these problems. Under the name of the collectivity, the peasants could work for themselves. This system is described by an expression: "hang the sheep's head in order to sell dog's meat" (guazhe yangtou mai gourou 挂着羊头卖狗肉, which can be translated by "cry up wine and sell vinegar").

This was a very important model, and was christened "the model of the three unions" (sanjiehe 三结合), which were:

- the union of families and collectivities;

- the union of collective production workshops in an economic confederation;

- the union of specialised producers and services for companies.

This system proved to be effective, and even enjoyed a certain degree of success, which helped it to grow and become more established. Indeed, it soon attracted the attention of neighbouring communes in addition to that of the higher political authorities, in particular those of the county of Yongkang and the prefecture-level city of jinhua. The government in Yongkang legitimised the system by launching the slogan of the "Four wheels turning together" (sige lunzi yiqi zhuan 四个轮子一起转) in 1984, celebrating the synergy between family households, the economic confederation, and village and town authorities.

Taken up and largely followed in the whole of the Yongkang area, the example of Mantang allowed the regional economy to swiftly take off. Meanwhile, the collective production workshops (shedui qiye) transformed themselves into rural companies (xiangzhen qiye 乡镇企业) as early as
1984. Therefore, four types of companies could be found in Yongkang by the end of 1985: 295 rural factories affiliated with the township, 525 rural village factories, 913 confederated factories, and 1,962 independent workers. (23)

Summing up this first period in the 1980s, it can be seen that the result of the deregulation started in 1978 by the central government, which gave rise to a certain reduction in the forms of centralised interventionism that had previously prevailed, was to allow the authorities at the most local levels to solve their own problems within the newly introduced frameworks. In the village of Mantang in Yongkang, this initially gave rise to a violent confrontation between small-scale craftsmen who wished to open and develop their own family workshops, and the local collectivities that intended to prevent them from doing so, not only in the name of the principles specified by the central authorities, but also in order to safeguard their own local system of collective companies. Having seemingly arrived at an impasse because it effectively paralysed an entire village - the conflict was solved by adopting a compromise in the form of the "red hat" system, supplemented by a mode of local organisation that allowed private activities to be established with a greater degree of freedom. Initially instituted locally by the "three union model" slogan, the experiment was taken up, extended, and legitimised at the municipal level by the city of Yongkang, celebrating the new synergy at work between family households, the economic confederation, and village and town authorities.

Such was the context in which Yongkang's local system began to take shape following the decentralisation (difang fenquan 地方分权) and the transition economy implemented at this time in China, ${ }^{(24)}$ as the city developed its activities in the sector that it knew best: small-scale metal working.

At this initial stage, it should be noted that the economic actors and village authorities succeeded, not without setbacks and problems, in outlining and honing an economic model that brought the authorities in the townships (xiang 乡), towns (zhen 镇), and villages (cun 村) together with the cooperatives (lianhu 联户) and private companies. Through this system, whose informal beginnings gave way to institutional recognition - albeit retrospectively - a new form of governance was able to find a footing in the local economy during this transition phase, in the form of an organisation trying to generally manage the coexistence and development of activities both public and private.

\section{Industrial take-off and the institutionalisation of clusters in the 1990s and early 2000s}

It was in the 1990s, and more specifically after Deng Xiaoping's journey to Shenzhen in 1992, when he recognised and even openly encouraged the liberal economy in China, that a notable shift occurred, resulting in a veritable explosion of industrial operations. This liberalisation of the economy, which allowed peasants and small-scale businessmen to consider setting up their own commercial and industrial activities on the national or even international scale, was to give free rein to the development of economic forces that had previously been latent or had yet to take shape. There would

23. Chen Qibiao, "Dui jinqi Yongkang xiangzhen qiye fazhan de huigu" (Retrospective on the Development of Rural Factories in Yongkang), op. cit. p. 18.

24. Jean C. Oi, "The Role of the Local State in China's Transitional Economy," The China Quarterly, No. 144, 1995, pp. 1132-1149. 


\begin{tabular}{|c|c|c|c|c|c|c|}
\hline \multirow{2}{*}{ Year } & \multirow{2}{*}{$\begin{array}{l}\text { Number } \\
\text { of } \\
\text { clusters }\end{array}$} & \multirow{2}{*}{$\begin{array}{l}\text { Value of industrial } \\
\text { production in Zhejiang } \\
\text { (billion yuan) }\end{array}$} & \multirow{2}{*}{$\begin{array}{l}\text { Proportion of the } \\
\text { value of industrial } \\
\text { production in Zhejiang } \\
\text { accounted for by } \\
\text { clusters }(\%)\end{array}$} & \multicolumn{3}{|c|}{$\begin{array}{l}\text { Distribution of companies } \\
\text { in the clusters according to the value } \\
\text { of their industrial production }\end{array}$} \\
\hline & & & & $\begin{array}{c}1-5 \text { billion } \\
\text { yuan }\end{array}$ & $\begin{array}{c}5-10 \text { billion } \\
\text { yuan }\end{array}$ & $\begin{array}{c}>10 \text { billion } \\
\text { yuan }\end{array}$ \\
\hline 1996 & 306 & 266 & 38 & 91 & 13 & 4 \\
\hline 2000 & 519 & 599 & 49 & 118 & 26 & 3 \\
\hline 2003 & 430 & 1,021 & 60 & 149 & 35 & 26 \\
\hline 2004 & 601 & 1,582 & 64 & 202 & 46 & 37 \\
\hline
\end{tabular}

Source: According to Sheng Shihao and Zheng Yanwei, "Jingzheng youshi: Zhejiang chanye jiqi yanbian he fazhan yanjiu" (Competitivities: Study on the Evolution and Development of Industry in Zhejiang), Hangzhou, Zhejiang daxue chubanshe, 2009, p. 34; Shen Jianming, Xu Dake, and Lei Chaolin, "2005 nian Zhejiang kuaizhuang jingji fazhan baogao" (2005 Report on the Economic Development of the Clusters in Zhejiang), 25 February 2012, www.xzbu.com/1/view-234951.htm (accessed on 13 June 2015); Zhejiang sheng jingji maoyi weiyuanhui (Economic and Trade Commission of Zhejiang Province), "Zhejiang kuaizhuang jingji fazhan baogao" (Report on the Economic Development of the Clusters in Zhejiang), 4 July 2006, www.zj.xinhuanet.com/magazine/2006-07/04/content_7430135.htm (accessed on 10 August 2015).

be a particularly high rate of growth in Zhejiang, owing to the fledgling industries that had taken shape locally during the preceding period.

\section{The explosion of industrial activities in Zhejiang and Yongkang}

Between 1996 and 2004, the number of clusters in Zhejiang doubled, while the value of their industrial production increased six-fold (see Table 1). In 2004, the 601 clusters were comprised of approximately 310,000 companies covering the main sectors: textiles, electrical goods, industrial equipment, metal products, electronic goods, leather, etc. Of the 90 districts and cities in the province at the time, 82 were categorised as industrial clusters. ${ }^{(25)}$

The expansion of industrial activities in Yongkang in this period was equally remarkable. In less than a decade, Yongkang grew to become one of the top 100 counties in China in terms of industrial production, achieving the $70^{\text {th }}$ position in 2001 and $47^{\text {th }}$ in $2005 .{ }^{(26)}$ As in the rest of the province, Yongkang experienced a veritable explosion in the growth of its companies, which increased their specialisation in metal working activities while also diversifying their production in this sector. In 2001, more than 11,000 varieties of metal product were registered there, approximately one hundred of which covered a third or more of the Chinese market. (27)

This period saw a massive transformation of the family workshops, the majority of which became full-scale companies operating in various sectors concerned with the production of metal goods. (28) Moreover, many new companies were created, considerably expanding and diversifying production and allowing a move to more upmarket operations.

In this way, Yongkang shifted from producing basic metal tools, cooking utensils, and small household items to operations outputting greater volumes of goods but also products that were technically and technologically more complex, such as metal doors, locks, mountain bikes, cylinder heads for engines, spare parts for motor vehicles, small motorbikes, small electrical tools, etc. By 2004, the city's economy was structured by seven sectors of activity. (29)

This major development was not without its effects on forms of local governance, especially since privatisation policies and the search for ways out of the planned economy helped profoundly transform the context and change the rules of the game.

\section{The paths of transition: Privatisation and transformation of the statutory framework of companies}

Owing to the reform of the legal status of companies and the privatisation process that had been put in place, the change in the scale and level of economic production of companies touched upon above went hand in hand with a diversification and transformation of their legal statuses.

Indeed, in 1994, a major process of privatising collective companies was initiated. These companies switched from the status of collective companies with a responsibility contract (chengbao hetong 承包合同) to that of shareholding collective cooperatives (gufen hezuo qiye 股份合作企业). At the end of the 1990s, the movement became more marked with the general privatisation of companies, which became either shareholding collective companies (gufen hezuo gongsi 股份合作公司) or limited liability companies (zeren youxian gongsi 责任有限公司). ${ }^{(30)}$

These important transformations on an economic and legal level resulted in a deep-lying diversification of company models. Thus, in Yongkang, family companies, collective rural companies, limited liability companies, and even early industrial groups rubbed shoulders with each other. The local system

25. Shen Jianming, Xu Dake, and Lei Chaolin, "2005 nian Zhejiang kuaizhuang jingji fazhan baogao" (2005 Report on the Economic Development of the Clusters in Zhejiang), Zhengce Liaowang, No. 7, 2006, pp. 5-9.

26. Lu Wei, Yongkang wujinye fazhan guochengzhong de chanye jiqun yanjiu (Study on the Industrial Clusters of Yongkang in the Development of the Metal Sector), Masters dissertation, Donghua University, Shanghai, 2005, p. 27

27. Ibid., p. 33

28. Our interviews with companies revealed many cases of such changes, for example that of the vacuum flask company cited earlier: "I am proud to have transformed a family workshop into a modern factory. In 1995, when I was manufacturing mechanical pencils, I started producing electronic scales, because it was a product that was selling well at the time. In 2000, I started manufacturing vacuum flasks. It was a speciality in Yongkang, where there is a whole chain of production." (Mr. Lu, interview from 2009). In order to form an idea of the rate of growth seen here, it should be noted that in 2009, when we saw Mr. Lu again, he had become the owner of a company with 1,400 employees and a turnover of 120 million yuan. In September 2011, his company became the first in Yongkang to be listed on the Shenzhen stock exchange.

29. Lu Wei, Yongkang wujinye fazhan guochengzhong de chanye jiqun yanjiu (Study on the Industrial Clusters of Yongkang in the Development of the Metal Sector), op. cit., p. 33.

30. Gilles Guiheux, "The Revival of Family Capitalism: A Zhejiang Entrepreneur," China Perspectives, No. 58, 2005, pp. 22-31. 
was transformed at an even deeper level by the fact that, at another level, the rules of the game opening the way to privatisation were changing. In 1995, the central authorities passed a new reform relating to the separation between the control and management of companies (guanban fenli 管办分 离). Whereas previously, only businessmen and local economic actors had been authorised to operate in the economy, this law allowed new actors onto the scene. It introduced the possibility of creating private companies and intermediate organisations authorised to intervene in economic processes, and made it possible to form associations of businessmen, branch associations, chambers of commerce, etc., and legitimised their actions. At the end of the 1990s, the National Commission for economic reform (quanguo jingji tizhi gaige weiyuanhui 全国经济体制改革委员会) drove this political will to separate the different domains still further forwards, by uncoupling the role of political power from the specifically economic sphere to an even greater degree.

\section{Yongkang: Responses and adaptations of the modes of public intervention}

In this new context of intense economic expansion, a proliferation of companies and a profound transformation of company models, local governments needed to transform their own actions, especially because these changes went hand-in-hand with the emergence of new institutional actors, both private and public, and the introduction of new rules governing operations between the actors. During this period, the mode of intervention adopted by the local authorities in Yongkang moved towards playing a more direct role in terms of providing facilities via the establishment of infrastructure and services, making a major contribution in terms of structuring the area and organising it into specialised clusters. These interventions mainly involved land-use planning on a local level and the provision of facilities offering direct support to trade and innovation.

\section{A role in land-use planning}

Following its swift economic expansion, the city of Yongkang found itself faced with a major problem in terms of space and infrastructure at the start of the 1990s. Despite diversifying to a certain extent in terms of the goods it was producing, the city's industry was still, in effect, heavily reliant on low-cost products (household items, small tools, etc.). The old specialised areas of production were found to be unsuited to meeting the new demands being made of them in terms of both capacity and quality. Moreover, many companies left the city towards the end of the 1990s in order to expand, most re-establishing themselves in neighbouring districts, which led to speculation and blockages. The owner of the Sunshine Company, whom we met at the time, gave the following account:

The major problem in Yongkang is land speculation, with prices reaching 3,000 or 4,000 yuan per square metre. On top of this, the city sets quotas. Applications need to be submitted every year, and when the quotas have been reached, it is impossible to obtain any more land. That is why companies go elsewhere.

This situation forced the local authorities in Yongkang to react and adapt their actions in order to better regulate the redeployment of economic activities. This they did by creating new industrial areas. In 2009, a former official from the Yongkang city administration described this process:
The village of Qianhuang, on the banks of the river Huaxi, started by exploring a 59-acre plot of land near the river, in order to install dozens of family companies there. This prompted the local authorities to explore vacant land on the hills of Yongkang. The Yongkang government subsequently built an industrial area and rented out plots to companies. A series of industrial estates was built in this way, hosting up to 3,800 companies at the start of the 1990 s.

It should be noted that this land-planning role was subsequently taken up and developed by the provincial government in Zhejiang. In 1999, it decided to establish new industrial estates in a more widespread manner in the province, based on the model that had been tried and tested in the province. Almost 100 specific industrial estates (tese gongyeyuan qu 特色 工业园区) and 100 specialised areas of industrial districts (xiangzhen gongyeyuan qu 乡镇工业园区) were developed in this way in provincial territory. (31)

\section{A role supporting trade}

The success of the industrial clusters in Zhejiang was largely down to the close links they were able to develop between production and marketing activities. Indeed, certain cities in the province, such as Yiwu, set themselves up as clusters in their own right, not to produce industrial goods, but instead to market these produced goods throughout the province and even on a national scale, with networks branching out into other provinces. ${ }^{(32)}$ As previously noted, this was one of the main assets behind Zhejiang's success. ${ }^{(33)}$ The local government of Yongkang followed this example on its own scale, and even supported this movement.

Starting in the second half of the 1990s, for example, it started encouraging companies to strengthen their link between production and trade: "Stimulating industry through trade and developing industry together with trade" (yi shangcugong, gongmao liandong 以商促工, 工贸联动). It also undertook to build, with the other local actors, the Technological City of Metals (wujin jishucheng 五金技术城), which opened in 1996. This is a specialist market bringing together producers and traders operating in the various branches of production in the area. This facility plays host to various specialist fairs and exhibitions at both a national and international level, (34) including, for example, a fair showcasing metal door production, this being an important sector for Yongkang, which accounts for $80 \%$ of metal door production in China.

\section{A role supporting innovation}

The other major area of intervention by the municipal authorities related to facilities supporting innovation, for example the creation in 1999 of the Innovation and Service Centre in Yongkang, providing a genuine service platform intended for companies. This is a half-private, half-public organisation,

31. Sheng Shihao and Zheng Yanwei, Jingzheng youshi: Zhejiang chanye jiqi yanbian he fazhan yanjiu (Competitivities: Study on the Evolution and Development of Industry in Zhejiang), Hangzhou, Zhejiang daxue chubanshe, 2009

32. Ding Ke, Distribution System of China's Industrial Clusters: Case Study of Yiwu China Commodity City, Discussion Paper, IDE-JETRO, No. 75, October 2006.

33. Shi Lu and Bernard Ganne, "Understanding the Zhejiang Industrial Clusters: Questions and Reevaluations," op. cit.

34. In Yongkang in 2005 there were as many as 67 specialist markets, 12 of which concerned metal products. 
$50 \%$ of its resources coming from the state (the central state, the province, and the city of Yongkang), while the remaining 50\% results from activities carried out by the centre. It acts as an intermediary between companies and research, helping companies design products, innovate, and obtain patents, and offering consulting services, etc. in all areas concerning the metal industry. It has a test laboratory, and can also provide premises, allowing it to play the role of a business incubator.

\section{New socio-political mixes and new modes of governance}

Another observation that can be made of Yongkang in the 1990s is that not only did the area of intervention of the local public authorities shift significantly, but that the modes of intervention themselves were transformed as well. These transformations resulted from the profound socio-political shake-up and major public/private readjustments that were then taking place, and that intensified under the swift economic expansion of the time.

The deregulation and the breaking down of public/private barriers also had a profoundly disruptive effect on the circumstances and the structures of both public and private local actors.

\section{Public actors}

With the privatisation policy and the resulting separation between the economic and political spheres, the local government found itself withdrawn from the economic sphere, where it was no longer supposed to play the leading role of a direct actor. In order to do so it would need to find other avenues. The structure we have looked at was rather built upon a collective management of the economic market, based on "small government and big market" (xiao zhengfu, da shichang 小政府, 大市场), as summed up by the motto promoting the changes: "The government guides, the administration cooperates, civil society participates, and the peasants remain the hard core" (zhengfu yindao, bumen peihe, shehui canyu, nongmin zhuti 政府引 导, 部门配合, 社会参与, 农民主体).

In this new context, the intermediate organisations would now not only play an economic role, but would also act as an interface in consulation with the local authorities and under their cover. The impact in Yongkang could be seen instantly, with management of the Technological City of Metals officially shifting into private hands in the form of the National Company of the Technological Market of Metals of Yongkang (Yongkang Zhongguo keji wujincheng youxian gongsi 永康中国科技五金城有限公司), which brought together various public and private partners. It should nevertheless be noted that the local government, as the main shareholder, retained a prominent role in decisions made by the company.

Indeed, what really characterises this phase was the degree of political and economic mixing taking place. The links between the state apparatus and companies had never been looser. That said, they reformed and adapted to the new private structures that were being established, with movement taking place in both directions. Admittedly, the local government no longer intervened directly as an entrepreneur in local economic life, but it did indirectly regulate activity by playing a part in the various structures implemented to provide support to companies, and through its continuing management role in major operations concerning land use and services. It also drew benefit from the indirect - though also more informal - links that remained or were formed during this period with new businessmen from the public sector. For example, in the major shift that took place towards the private sector at this time in Yongkang, the new company bosses were very often former managers of rural collective workshops, or former local political officials, or indeed had been sales or technical managers in collective companies. ${ }^{(35)}$ Additionally, when free elections were introduced in the villages of the area, many businessmen became political leaders in the local organisations. In 1996, $40 \%$ of positions of responsibility in the villages were thus held by businessmen (this proportion passed $60 \%$ in 2002). (36) The overall result was a thorough shake-up at the local level between the various economic and political actors.

\section{Businessmen}

The position and interaction of businessmen in the local system have also changed. The local government continues to act as a privileged collaborator with companies, and its support is essential in order for them to prosper. This support enables companies to obtain information and assistance more quickly, for example when acquiring land to accommodate company expansion, and in the form of support for innovation by research centres linked to the local government, or tax exemption. Becoming a member of various political bodies allows private businessmen close access to political power and to enjoy its support, thus ensuring the success of the company. It should be noted that, on a local basis, companies in Yongkang - and without doubt in many other cities - are judged less in terms of their performance on a purely economic level than on their ability to pay their taxes and be involved locally. It is partly on the basis of these criteria that the merit list and ranking of companies are drawn up, forming the basis for the allocation of assistance and services established locally. ${ }^{(37)}$

The 1990s and early 2000s therefore constituted a decisive period in Yongkang's development, not only because of its extraordinary economic expansion, but also because it was during this period that the specific forms of its organisation into an industrial cluster specialising in metal working developed and took a clearer shape.

Therefore, within a period of ten years, a system rooted in "parcelled economy activities" that was spatially very narrow and economically limited on

35. A number of cases presenting similar trajectories came to light during our interviews in Yongkang, including that with the founder of a company producing small electrical tools, which is well on the way to becoming one of largest firms in this industrial sector in China. The company founder, Mr. Wang, had worked in Yongkang in the state tractor factory, where he was responsible for production management. In 1989, at the time that rural companies were starting to grow in number, he joined a factory created by the township authorities, where he was responsible for purchasing raw materials. Six years later, in 1995, when the legal status of companies was changed, he decided to set up his own company specialising in bottom-of-the-range electric tools (drills, surface-planing machines, saws, etc.) for the Chinese market and, later, for overseas markets (Carrefour, Castorama, Metro, etc.). The company grew very quickly and is today one of the more influential companies in Yongkang.

36. Village organisations consist of three committees: the committee of the Chinese Communist Party, the village committee, and the collective cooperatives committee. See Lu Fuying, "Nongcun siying qiyezhu de jueqi he canyu: yi Zhejiang Yongkang shi sige cun weili" (Increasing Numbers of Businessmen and their Participation in Local Political Life: The Case of Four Villages in Yongkang in Zhejiang), Shehuizhuyi yanjiu, No. 6, 2007, pp. 135-137.

37. Each year, the government in Yongkang organises a competition for companies, which produces an official ranking of the 100 best companies and a merit list. Some businessmen place great importance in this merit list, and compete to always improve their ranking, in particular in respect of paying more tax. From their perspective, this "political honour" shows the good health of the company and facilitates access to plots of land, assistance from the local government, and services. For example, the vacuum flask company and tool company jiake that we visited occupied the $11^{\text {th }}$ and $49^{\text {th }}$ positions, respectively, in this ranking in 2010 . This meant they held priority positions when it came to acquiring plots of land in the new industrial area. 2010 nian Yongkang shi nashui baiqiang qiye mingdan (The Top Hundred Companies in Terms of Tax Payments in Yongkang in 2010), http://wenku.baidu.com/view/c58f697ca26925c52cc5bf37.html?re=view (accessed on 10 October 2014). 
account of its small-scale nature, grew into a highly structured area capable of standing on its own two feet and emerging as a specialised cluster. This transformation was made possible by the evolution of the economic framework. Indeed, it could not have taken place without the deep-lying changes in modes of governance and in the new roles attributed to local governments, which uncoupled the economic and political powers, introducing new types of mixing and interaction between public and private actors, and other forms of local public intervention that took direct responsibility for the facilities of the cluster, tied in with the multiple economic actors involved. On the strength of these transformations, how would the new cluster subsequently be able to sustain these advances?

\section{From industrial clusters to cluster networks: Towards new forms of governance?}

\section{The context}

In the middle of the 2000s, Yongkang therefore emerged in Zhejiang Province as a dynamic and flourishing industrial cluster, whose activities were both particularly well integrated locally and also open to the outside world. In 2006, the city had more than 15,000 private registered firms, including 83 electric tool companies, 40 involved in casting and sheet metal forming, 50 appliance manufacturers, 45 steel plants, etc. Of the 15,000 companies, some 3,000 sold their finished products outside China, while another 12,000 served as subcontractors, suppliers, or distributors. ${ }^{(38)}$ Together, they formed a dense network of companies relatively well integrated with each other and operating according rules that, despite being more or less unspoken, were nevertheless relatively well observed (honouring of engagements, fixed production sites, and the preservation of client and supplier networks). In other words, they functioned as a full-scale cluster, giving Yongkang its competitive advantage. (39)

The period was not without its setbacks, however, and Yongkang had to face up to a series of difficulties throughout the 2000s.

\section{The problem of changing production demands}

The expansion of the Yongkang area and the diversification of metal production operations were undoubtedly important, but they continued to be too heavily reliant on low-cost products such as household items, small tools, etc. that were manufactured in often polluting industrial sectors. The existing clusters therefore struggled to adapt to the new demands that were being made of them, in particular to improve the quality of their products; they also found it difficult to comply with the new environmental requirements introduced by the government at both the central and provincial level.

At another level, a number of companies that were experiencing sharp growth urgently needed to expand, but Yongkang was no longer in a position to provide them with new land. This led many companies to leave the city at the start of the 2000s. Some went to re-establish their operations in neighbouring counties, while others uprooted their operations to other Chinese provinces in moves that allowed them not only to acquire new spaces, but also to benefit from advantageous tax and duty arrangements, and indeed cheaper labour.

What is more, these problems arose at the time of the global financial crisis of 2007-2008. The second part of the 2000s were a particularly difficult time, marked principally by flagging exports and an increase in the cost of raw materials and labour, all of which were further exacerbated by the financial situation. The SMEs in Zhejiang were particularly hard hit, and whole clusters, such as those in the city of Wenzhou, were heavily affected.

These various difficulties forced the authorities in Yongkang to implement new forms of development and to rethink, in particular, their territorial rooting. The modes of intervention and governance were, for their part, profoundly redefined.

\section{Intensification and transformation of local government actions}

In this new phase, the government in Yongkang intended to play a role of supporting and assisting companies, offering services in three main areas: ${ }^{(40)}$ the creation of specialised centres providing services to keep companies in the area, an extension of the policy of innovation and modernisation of industry, and assistance with restructuring. The overall aim was to transform the local framework and stage in order for companies to be able to play a full role (the government would set the stage, and the companies would play the roles, zhengfu datai, qiye changxi 政府搭台, 企业唱戏). The result of this policy of "upgrading" the various sectors offering companies assistance and services was to open the way to another way of organising the cluster, this time on a broader base.

\section{The creation of specialised centres and services for companies}

In addition to the avenues previously developed to provide general support to companies (in land-use planning and support for trade and innovation) and without abandoning them, the city of Yongkang was able to further its interventions by making them increasingly targeted and specialised.

For example, in 2007 it created five specialised service centres for companies: a registered office centre, a fairs centre, a logistics centre, an innovation and service centre, and a customs centre. In 2011, a further five centres were being brought into existence relating to the fields of quality control, industrial creation and design, international logistics, human resources, and the more specific sector of producing industrial moulds. The aim was to directly provide local businesses with a whole range of specialist assistance and advice throughout the various stages involved in realising a product, offering help on-site in terms of advice and quality.

To take one example, the registered office centre (zongbu zhongxin), built between 2008 and 2012, was designed to accommodate more than 500 companies. It was aimed, in particular, at those companies in Yongkang that had moved their production operations out of the city owing to an inability to acquire land, as well as at new companies arriving from outside. The centre's policy was also geared towards keeping companies who paid their taxes in the city of Yongkang by offering them offices, in addition to numerous services such as a banking, information, foreign trade, etc.

\section{Repositioning the channels of innovation in regional and national policies}

The main action of the municipality was to ensure that local innovation policies fell within the scope of the major national and provincial guidelines.

38. Victor Nee and Sonja Opper, Markets and Institutional Change in China: Capitalism from Below, Cambridge, MA, Harvard University press, 2012, p. 133.

39. Ibid., p. 148

40. Interview with the deputy mayor of Yongkang in May 2011 


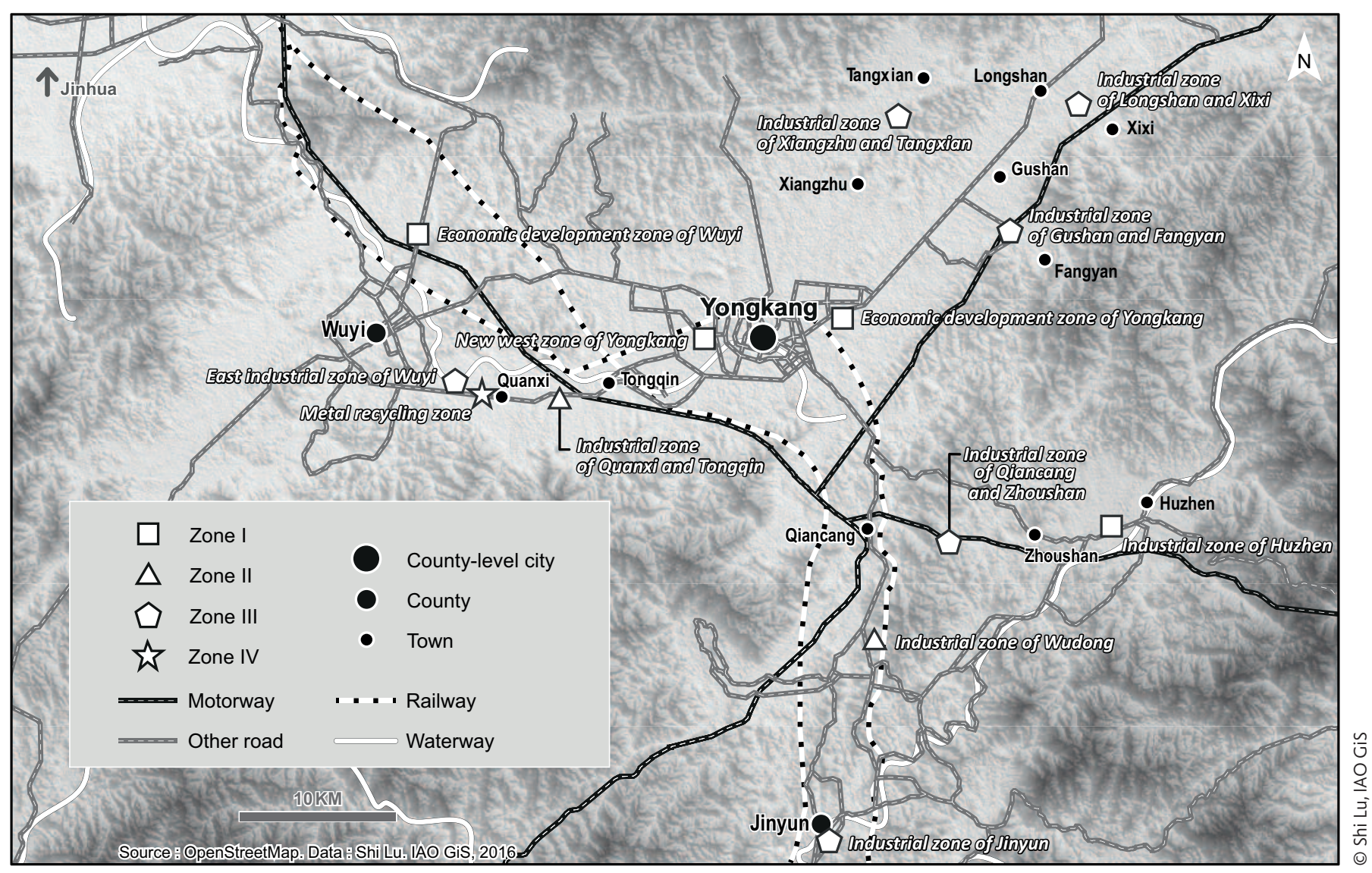

In the context of the $12^{\text {th }}$ five-year plan (2011-2015), the central authorities established a policy promoting innovation and high technology with the aim of moving into a new phase of industrial development. In the case of Zhejiang, the government identified three main areas in which it could face up to national and international competition: innovation, environmental protection, and a social policy favourable to migrant workers. In terms of innovation, moving upmarket and the promotion of high technology became priorities. The province therefore helped fund the creation of research centres and innovative projects, identifying 42 high-technology clusters. Of the 12 priority activity sectors defined by the central government, and the five chosen by Zhejiang Province, Yongkang selected two: electric cars and new energies (solar and photovoltaic energy). As a result, a chain of production of electric vehicles for farmers and craftsmen was set up in 2011, using Japanese technology.

With the construction of a new $10 \mathrm{~km}^{2}$ motor vehicle production area, the city expected in 2015 to welcome five manufacturers with a total production capacity of one million cars. ${ }^{(41)}$ A subsidy was offered to innovative companies in this sector.

\section{Incentives for the restructuring and technical renovation of SMEs}

In order to renew the industrial infrastructure, which was still strongly characterised by the position occupied by cheap, low-technology products, the government of Yongkang drew up a series of measures and financial assistance schemes to encourage family concerns to restructure themselves into shareholding companies.
Similarly, as regards facilities, the local government contributed financially to investments made by companies fitting out their premises in accordance with new environmental standards by covering $10 \%$ of the cost of equipment produced abroad, and between $4 \%$ and $6 \%$ for Chinese equipment, depending on the sector.

The policy of providing specialised services to companies, the desire to modernise the local industrial infrastructure, and the wish to ensure that local industrial activities were in line with the priority sectors chosen and stated at the national and regional levels, were all concerns that meant that the local authorities had transformed the organisation of the metal working cluster of Yongkang by the early 2010s.

\section{Redeployment of the area on a wider base: Cluster networks}

Starting in 2007, Yongkang embarked on a new phase of its industrial development. Aiming to channel these new changes while conserving the synergy characteristic of clusters, these new clusters, built in rural areas, were no longer limited to a single administrative location, or to a single sector of activity. They brought together companies with a variety of activities in an inter-county area (kua chanye, kua xianyu 跨产业, 跨县域), thus forming new economic centres (jingji quan 经济圈) and defining new types of inter-

41. Lu Yuedong, 2011 nian Yongkang shi zhengfu gongzuo baogao (2011 Statement of Accounts of Yongkang Government), speech made at the fifth plenary session of the $15^{\text {th }}$ session of the People's Congress of Yongkang on 8 March 2011, www.newykr.com/public.asp?action=news_detail\&typesid=9\&id=732 (accessed on 20 June 2015). 
county, multi-activity clusters (kua chanye kua xianyu jiqun 跨产业跨县域 集群). ${ }^{(42)}$

The newly established cluster or economic centre straddled the three administrative units of Yongkang, Wuyi, and Jinyun. It extended over an area of $2,000 \mathrm{~km}^{2}$, with Yongkang located at its centre, some $20 \mathrm{~km}$ from each of the other two counties. Since 2001, more than 1,000 companies had set up in these areas, and of all of the companies moving in, $62 \%$ were from Yongkang, 20\% from Wuyi, and 18\% from Jinyun. ${ }^{(43)}$

The government of Yongkang therefore committed to making this area into a model modern cluster. Selected from the 21 pilot innovation clusters in the province, ${ }^{(44)}$ the economic centre of Yongwujin 永武晋 (for Yongkang, Wuyi, and jinyun) would become, by 2010, the first county-level city in the province to have completed, via the "inter-county and multi-activity" label, its structural innovation and transformation project. ${ }^{(45)}$ The new economic centre of Yongwujin (Yongwujin chanye jiqun 永武晋产业集群) was organised into four areas (see Map 1): the economic development area of Yongkang (Yongkang jingji kaifaqu), the new area in West Yongkang (Yongkang cheng xi xinqu), the Wuyi economic development area (Wuyi jingii kaifaqu), and the industrial area of the town of Huzhen (Huzhen gongye gongnengqu), each specialising in a certain field.

The first economic and development area, in Yongkang, is the centre of the metal industry and provides the technological linchpin. This is where eco-friendly cars are manufactured, as well as being the site of the registered office centre, service centres, etc. The second area is set aside for the production of motorcycles and is more focused on subcontracting activities (spare parts for cars, various metal products, etc.). The third area is home to industrial estates designed specifically around flagship products. The last area is located in a more rural setting, where industrial production is more scattered and without any particular specialisation.

Organised into a network, these new clusters brought several existing industrial estates together (reorganised around the main linchpin of Yongkang), technological parks and service centres. Production was to be diversified in these new clusters, shifting from metal tools for agricultural or household work to spare parts for motor vehicles, copper processing, the manufacture of motorcycles and cars, etc. The new industrial areas, each separate from the others but remaining part of the same structured networks, represented a new way of organising the clusters - possibly even a new concept - attempting to supplement the initial "specialisation" of the clusters with complementary features and openings with regard to services and networking. Regardless of their size, companies could organise themselves to adapt to this new economic environment. Some did indeed readjust their market and outlook, remaining in Yongkang to develop; ${ }^{(46)}$ others diversified their activities, or indeed their installations, ${ }^{(47)}$ while yet other developed their innovations, or created their brand and looked to the international markets. ${ }^{(48)}$

It is, of course, too early to assess the real impact of these measures and take stock of a policy that was, after all, introduced recently. What matters for the purpose of this article is that, changing the scale and period, the political and economic stakes for Yongkang have been profoundly modified. The role of the municipal authorities has also transformed, with the mode of governance in Yongkang having extended, diversified, and shifted during this time.

In this most recent phase, it was no longer a case of bringing it about by channelling and structuring an endogenous development in the manner of the previous phase; it was rather a case of updating the former low-cost in- frastructure and its harmful effects on the local environment, modernising the area to bring it up to the standard required for the international markets, and making this possible by developing innovation and new technological sectors, while rethinking and redeploying the economic and spatial organisation of the area and the old clusters on a more adequate footing.

It would not have been possible to carry out this large-scale work without implementing broader industrial policies. Securing the direct involvement of the provincial and national levels and working in close collaboration with them was crucial, if only to benefit from the effects of the major economic strategies decided upon and driven forward by these levels, and the means implemented in order to realise them.

The city's actions have therefore been characterised by a system of implementation better coordinated with these various external authorities and also more incentivised with regard to the local actors. This has been seen in the close cooperation with the state and province in order to tie in with the development sectors successively defined by the two; greater cooperation with other municipal and urban entities and the provincial and national authorities in order to reorganise the whole area and establish inter-county and multi-activity clusters; various examples of incentive aid aimed at profoundly transforming the local company infrastructure to leave behind the low-cost past and put in place infrastructures offering specialist services and advice, and centres to assist research and innovation, etc. In short, the intention was to provide a service-oriented government playing

42. Wei Jiang and Gu Qiang, Zhongguo chanye jiqun fazhan baogao (Report on the Development of Industrial Clusters in China), Beijing, China Machine Press, 2009

43. Yongkang shi gongye jingji fazhan jiaoliu cailiao (Document on the Industrial and Economic Development of Yongkang), 25 April 2011. Internal working document from the city administration seen during our interview with the deputy mayor of Yongkang.

44. Sheng Shihao and Zheng Yanwei, Jingzheng youshi: Zhejiang chanye jiqi yanbian he fazhan yanjiu (Competitivities: Study on the Evolution and Development of Industry in Zhejiang), op. cit., p. 288.

45. Ying Wenying, "Yongwujin wujin chanye jiqun gongye yuanqu fen siceng buju" (The Four Areas of the Industrial Metal-Working Cluster in Yongwujin), Yongkang xinwen, 6 January 2011, www.yknews.com (accessed on 30 January 2014).

46. The owner of the vacuum flask company whose development we followed in Yongkang explained his company strategy to us in 2009: "For the past three years, our work has focused in particular on reorganising management, mainly in terms of staff. I now take on experienced managers and also young graduates. From a technical point of view, I have hired a Japanese person for the chain of production. I have him come over from Japan every three months. We have been able to improve our products over recent years. We still specialise in vacuum flasks, and I want to be the best manufacturer here."

47. This applies to the case of the Sunshine Company, which chose to diversify into new selected technological niches (interview in 2011). After spending time as a workman in a collective factory, the company owner, $\mathrm{Mr}$. Chen, clubbed together with friends to produce spare parts for gas cookers (stoppers for closing the circuit in gas cookers). That was in 1989, when many Chinese homes were starting to acquire gas cookers. Mr. Chen was therefore able to make a lot of money. In 1995, using his savings (the "first pot of gold," diyi tong jin), he started manufacturing security doors, which were selling very well on the Chinese market. In 1999, his company started manufacturing electric bikes for the Chinese and international markets. Encouraged by the new innovation policy in the 2000s, Mr. Chen started producing electric cars. His company grew to become one of the three biggest firms in this sector. The company is now investing in the production of solar panels and in property. The owner has split the company into three with his son and daughter, each of whom is responsible for a specific sector: the owner deals with security doors and property, the son manages solar and photovoltaic panel production, and the daughter is setting up an independent company for manufacturing electric bicycles and cars. The choice of product is always made depending on the needs of the market, but care is also always taken to comply with local policy. At each significant change of product, Mr. Chen has been able to take advantage of local government assistance.

48. This is the case of the swiftly growing electric tool company liake, which has international ambitions. After initially working for foreign companies, including Bosch, Jiake created its own brand and started producing more upmarket products in 2006, shifting from small electric tools for the general public to tools for professionals and becoming an industrial group. The company worked for a long time with Bosch, initially as a supplier, but also now as a collaborator in product innovation. The group even patented an innovative new battery in 2008. At the end of the 2000s, while keeping its base in Yongkang, Jiake opened a new copper factory in Quzhou in Zhejiang, and a research centre in Shanghai to meet its specific demands. 
a major pivotal role at the various decision-making levels and adhering to the new public intervention model advocated in present-day China (the service government, fuwuxing zhengfu 服务型政府).

\section{Conclusion}

As a major flagship of Chinese industrial development, Zhejiang presents - through its clusters - a relatively original mode of development, differing in its deeply endogenous character from that seen in other areas of China, such as Guangdong, (49) as an examination of the development of the city of Yongkang clearly shows.

This essentially rural and relatively deprived area with no strong industrial base has been able to set up veritable sectors of activity specialised in metal work, to the point that it is today a relatively flourishing specialised cluster. Over a 30-year period, it has been able to establish the channels needed to allow its own expansion. Shifting from the small scale production of farm tools to the construction today of electric cars, evolving from a system rooted in "parcelled economy activities" to an organisation of "cluster networks," the configurations of local industry could barely be more contrasting, demonstrating a far-reaching ability to adapt, both economically and politically, combined with a high level of institutional flexibility.

At each step, it appears that the area of Yongkang has been able to grasp the possibilities opening up to it, whether this has meant forcing them, as in the initial spurt of growth in the 1980s leading to the cover of the socalled "red hat" system; fully embracing, at the time the clusters were forming in the 1990s, the dynamic created by the new political and economic shake-ups made possible locally by the introduction of laws relating to the transition and privatisations; or indeed not being afraid to change the approach and initiate a degree of restructuring to embrace new types of activities and new spaces, in order to face up to the globalised challenges of the early 2000s.

This development would probably not have been possible had it not been accompanied, on each step of the way, by a change in modes of governance. This saw a shift from a system of authoritarian local government in the first phase, requiring adaptation and compromise, to the second phase involving liberalisation and privatisation in a far more direct local mode of administration and management, in which the local collectivities and new economic actors acted as the driving force structuring Yongkang's specialised cluster. The desire of the area, at the start of the 2000s and faced with inevitable globalisation, to update part of the existing industrial fabric and promote the cluster's industrial credentials by taking it to a new technological level, helped modify local modes of intervention. The emphasis now shifted from the local situation to how this situation fitted into the wider context, whether spatial, political, or economic, where it was to evolve. Establishing the inter-county, multi-activity cluster, and adhering to the technological sectors promoted both nationally and regionally while updating the old industrial infrastructure, would lead to the establishment of modes of governance giving greater prominence to more indirect forms of intervention by placing greater emphasis on incentives, global coordination, regulation, and so on.

Beyond the case in question, what lessons can be learned from this?

Firstly, the forms of transition observed in Yongkang between the 1980s and 1990s bring to mind observations already made elsewhere concerning the shift from the authoritarian forms of "local corporatist" governance (in which the local authorities are directly involved in the collective companies, manage their investments, rule locally by deciding everything, etc.), to forms of intervention of a more directly managerial nature in the period of liberalisation of the economy, referred to as "post-local corporatism" (in which the local collectivities are more directly involved in the management and organisation of local development). ${ }^{(50)}$

Secondly, the observations made in Yongkang and Zhejiang most certainly make it possible to further our understanding of the changes taking place, as noted by other observers of development in this province.

For the latter, the success and originality of Zhejiang's clusters lie precisely in the mode of management closer to the ground that developed from and through the advent of liberalisation. Admittedly, during the 1990s, the central government deregulated, decentralised, put in place the framework for transition, and promoted privatisation. But while it did indeed provide an institutional framework, these general guidelines neither provided nor constructed the means to progress further in terms of practical action. There was no specific policy, for example, to assist clusters; the very term did not emerge until the beginning of the 2000s. In this transition phase in the 1990s, each cluster therefore worked to develop in its own fashion. In Zhejiang, and as we have seen in Yongkang, it was the system of locally managing local policies, based on the smallest local unit, the town, that helped build a series of diversified and adapted industrial structures, closer to the ground and in a new kind of socio-economic mixing. It was these structures that would give their form to the spaces later referred to more generally by the term "clusters." (51) A certain absence of specific intervention by the central government in the other layers of government appears to have allowed the local levels to model and structure themselves in the way they did, the framework being provided by the state, but with no specific help coming from the state. This "absence" can also be seen in the behaviour of the provincial government, which might be considered to be "lagging behind" somewhat at this time, following rather than leading initiatives developing locally at the time, even if it subsequently took over operations that proved successful, as previously noted. In this respect, as our authors conclude, the development of Zhejiang's local industrial clusters was driven forward "not only by technological products and processes, but also by the institutionalisation of their modes of management and organisation," which were constructed locally as close as could be to the spaces that were ultimately being administered. (52) The local systems therefore played a decisive role in this area, in the diverse and varied forms that they could take. This links in with the conclusions drawn in other works recently published by other economists in Zhejiang and jiangsu, showing how the development of the companies studied there between 2006 and 2009 took place largely through endogenous local channels, and the importance of therefore considering this form of "bottom-up capitalism" that is taking root if we are to grasp

49. Wang Jici, "New Phenomena and Challenges of Clusters in China in the New Era of Clobalisation," in Bernard Ganne and Yveline Lecler, Asian Industrial Clusters, Global Competitiveness and New Policy Initiatives, op. cit., pp. 195-212; Xu Jianniu, "Post Local State Corporatism: A Case Study of Local Government's Role in the Development of Industrial Cluster after Privatisation," in Bernard Ganne and Yveline Lecler, Asian Industrial Clusters, Global Competitiveness and New Policy Initiatives, op. cit., pp. 307-324

50. Bernard Ganne and Yveline Lecler, "From Industrial Clusters to Competitiveness Poles: New Assets for the Clusters? Introductive Elements," in Bernard Ganne and Yveline Lecler, Asian Industrial Clusters, Global Competitiveness and New Policy Initiatives, op. cit:; Xu Jianniu, "Post Local State Corporatism: A Case Study of Local Government's Role in the Development of Industrial Cluster after Privatisation," art. cit.

51. Zheng Yanwei and Sheng Shihao, "Understanding the Role of Government in Zhejiang Industrial Cluster Governance," International Workshop Industrial Cluster and "Competitivity Poles": Understanding the Transformation of Public Policies in France and China, ENS Lyon, 22-23 March 2012.

52. Ibid. 
the transformations currently taking place in China. ${ }^{(53)}$ In order to understand this phenomenon, it would be useful to further explore comparisons with the observations made not only in other parts of China, but also with the evolution of other clusters observed in Europe, in Emilia-Romagna or Bade-Wurtemberg, as has, on occasion, been initiated. (54) However, that would take us too far from our subject.

What is striking from the Yongkang case is how the local organisation of the area at no point lost flexibility, and how the predominantly local mode of operation adopted when establishing the cluster in no way prevented the city from opening up during the subsequent period to other, broader forms of operation.

Finally, it is worth highlighting how, in the highly rigid institutional context that seems to characterise China, the flexibility of Zhejiang's industrial clusters, in terms of institutional adaptation, is not surprising. Indeed, this flexibility has taken root in what could be seen as a deeprooted culture of compromise. At the heart of this is the practise of almost never directly challenging the stated general political principles or colliding head-on with institutions, instead circumventing difficulties in order to produce a de facto - and initially, almost surreptitious - acceptance of the obvious and the benefit of adopting new practices. The watchword of this culture is adaptability, which is capable - by means of many adjustments - of modifying situations from the inside in order to win the adoption of rules that can be quite contradictory, as can be seen in various consecutively stated principles of local governance from "cut off the capitalist tails" to "stimulating industry through trade and developing industry together with trade" (yi shangcugong, gongmao liandong) via the "four wheels (the local political and economic institu- tions) turning together" (sige lunzi yiqi zhuan) - always without direct conflict, especially political, and with care being taken to avoid loss of face. The system therefore functions somehow according to a mode of ex-post social recognition, avoiding "open crises," (55) but capable on the other hand of establishing - as we have seen here in the development of the industrial clusters - a dynamic of adaptation that is as powerful as it is constant.

Is this not one of the particularities of the forms of evolution of the current Chinese regime, in the context of the "socialist market economy" that it intends to promote and govern, while continuing to hold the political reins? (56) This is certainly not a point that we feel should be ignored if one is to understand the Chinese economy's speed of growth and ability to adapt, and when taking stock of its developments and ambitions. Indeed, is it not the very same type of cluster from Zhejiang, as observed and established in Yongkang or Wenzhou, that can now be found, with its own features in Cape Town, South Africa, ${ }^{(57)}$ or Prato, Italy, ${ }^{(58)}$ where it has even supplanted the former highly symbolic model of Italian industrial districts?

\section{Translated by Will Thornely.}

I Shi Lu is an associate professor in Chinese studies at Université Jean Moulin Lyon 3 and a researcher at IAO (Lyon's Institute of East Asian Studies).

ENS-Lyon, 15 Parvis René Descartes, 69007 Lyon

(lu.shi@ens-lyon.fr).

I Bernard Ganne is a sociologist and Emeritus Research Director, CNRS-CMW, ISH Lyon, Université Lyon 2.

14 Avenue Berthelot, 69007 Lyon (bernard.ganne@ish-lyon.cnrs.fr).
53. Ibid.

54. Xu Jianniu, "Post Local State Corporatism: A Case Study of Local Government's Role in the Development of Industrial Cluster after Privatisation," art. cit:; Lin Nan, "Local Market Socialism: Local Corporatism in Action in Rural China," Theory and Society, Vol. 24, No. 3, 1995, pp. 301-354; Feng Yusheng, "Chinese Villages and Townships as Industrial Corporations: Ownership, Governance and Market Discipline," American Journal of Sociology, Vol. 106, No. 5, 2001, pp. 1338-1370.

55. François Godement, "La Chine a du temps pour changer de trajectoire" (China Has Time to Change Trajectory), Les Échos, 7 November 2012.

56. David Shambaugh, China's Communist Party: Atrophy and Adaptation, Berkeley, UC Press, Washington, Woodrow Wilson Center Press, 2008.

57. Ding Ke, Market Platforms, Industrial Clusters and Small Business Dynamics: Specialized Markets in China, op. cit:; Ding Ke, "Distribution System of China's Industrial Clusters: Case Study of Yiwu China Commodity City," in Bernard Ganne and Yveline Lecler, Asian Industrial Clusters, Global Competitiveness and New Policy Initiatives, op. cit., pp. 267-306.

58. Gabi dei Ottati, "A Transnational Fast Fashion Industrial District: An Analysis of the Chinese Business in Prato," Cambridge Journal of Economics, Vol. 38, No. 5, 2014, pp. 1247-1274; Silvia Lombardi, Franco Lorenzini, Fabio Sforzi, and Flavio Verecchia, "Chinese Entrepreneurship in Context: Specialization, Localization and their Impact on Italian Industrial Districts," ERSA Congress Barcelona, 2011, www-sre.wu.ac.at/ersa/ersaconfs/ersa11/e110830aFinal00626.pdf (accessed on 12 November 2014). 